\title{
THE MEMORY OF GENOCIDE IN SINDIS NIHELI'S HIZAR AND THE VICISSITUDES OF LIFE, PART ONE AND PART TWO
}

\author{
LOLAV M. HASSAN ALHAMID \\ Dept. Of English, College Of Languages, University Of Duhok, Kurdistan Region-Iraq
}

(Accepted for Publication: January 30, 2019)

\begin{abstract}
This paper explores the tragic experiences of the Kurdish nation during the two brutal events that changed life in Kurdistan irrevocably; the Anfal Campaigns that began in 1986 and lasted until 1989, the genocide of the Yazidi Kurds in Sinjar in August 2014 and their aftermaths as represented in the contemporary Iraqi Kurdish novel in Bahdinan. Depicting the notable increase in the number of civilian casualties and addressing various forms of war-related and terrorism-related violence and the physical and psychological effects they inflect on the lives and experiences of the Kurdish people in Iraq, my study aims to answer such intriguing questions as: What is the impact of the atrocities of genocide on the Kurdish novelistic discourse? How has the Kurdish novel expressed the massacres of Anfal and Sinjar? Has genocide become a main theme in the Kurdish novel and hence aided the Kurdish national and political platforms in successfully conveying the extent of these horrific processes of extermination?

Emerging during the same decade as the occurrences of Anfal genocide, namely, the late 1980s, the Kurdish novelistic discourse by Bahdini writers increasingly represent the Kurdish genocide and its aftermath in their works within what I prefer to call "a memory wave" in modern Kurdish literature in Iraq. The memory of the genocide (both Anfal and Sinjar) is manifested in the Kurdish novel in Bahdinan through a number of recurring themes and leitmotifs such as bearing witness to acts of historical silencing and marginalization of the Kurdish people and their true history, retelling and rewriting the Kurdish tradition and, evoking a shared sense of collective memory and consciousness.

Focusing on Sindis Niheli's first and only novel, (Hizar di Werçerxana Da), Hizar and the Vicissitudes of Life, Part One, 2013 and its second part, published in 2014, with the same title, the study examines the ways in which Kurdish novelists in Bahdinan express their sense of responsibility to record the atrocities exerted against their nation throughout their recent and contemporary history. Furthermore, addressing the growing interconnection between civilian homes and battlefronts, which is one of the most defining characteristics of the genocidal Anfal campaigns and Sinjar massacres, a theoretical approach developed by Wenona Giles and Jennifer Hyndman's is adopted. Giles and Hyndman indicate that, unlike wars fought in the past, when civilian peoples' homes were safe and male soldiers fought enemies on battlefronts, "contemporary conflicts blur such distinctions, rendering civilian women, men, and children its main casualties." 1

My study concludes that the treatment of genocide memory in the Bahdini novels contributes to a genuine confrontation with its painful experiences and eventually establishes wider-scale efforts to formalize Kurdish genocide in the international community. It asserts that these texts provide the international community and the whole world with an understanding of the Kurdish national identity as distinct from the identities of the nation-states in which they live and allows a more critical recognition of their perpetual suppression. As such, these narratives have the potential to enable the Kurdish people to recognize and challenge the role of the superstructure in shaping public discourse about the Kurdish Genocide.
\end{abstract}

KEYWORDS: Genocide, Conflict Zone, Anfal, Sinjar, Kurdish People.

\section{INTRODUCTION: Genocide In The} Kurdish Context

7 he Genocide Convention of 1948 defines genocide as any acts "committed with intent to destroy, in whole or in part, a national, ethnical, racial or religious group, killing members of the group or causing serious physical or mental harm to members of the group." 2 This definition helps in identifying the bureaucratic destruction of the Kurdish people in 
Iraq in 1988 as genocide: "The Kurdish Genocide was centrally planned and administered by the Iraqi Government against the entire Kurdish population. In addition, the Kurdish people were also subjected to deportation, expropriation, abduction, torture, massacre, and starvation." (Kelly, 2008:18) The Anfal genocidal campaign was aimed at the complete extermination of the Kurds in Iraq by the Iraqi regime. According to Michael J Kelly:

There were multiple mass murders, multiple mass disappearances, forced displacement of hundreds of thousands of noncombatants, destruction of 2,000 villages that were classified in Iraqi government documents as "burned," "destroyed," "demolished," or "purified," and the razing of a dozen larger Kurdish towns and administrative centers. Altogether, 4049 villages were leveled. (Ibid.)

The influential report that followed the unanimous vote taken in February 28, 2013 before the British parliament foregrounded that "for the victims of Iraqi Kurdistan, formal EU recognition of the legacy of massive human rights violations is crucial to achieve a sense of justice and preserve the memory of the past."3 The vote, which the Kurdish Regional Government (KRG) describes as "a significant landmark for the victims of genocide," establishes an overwhelming support for the formal recognition and international acknowledgement of the crime of genocide committed against Iraqi Kurds by senior officials of the government of Saddam Hussein. The atrocities were effectuated by the policy of extermination administered against the Kurdish people in Iraq during the 1988 Anfal and Halabja military campaigns.

Similar pronouncements of acknowledgement and support by the Norwegian and Swedish parliaments has preceded the British vote and a draft resolution has been approved by the Swedish parliament to recognize and internationalize the Kurdish genocide. Moreover, both the United Nations and the European Parliament have organized conferences and events to commemorate the Halabje attack formally calling it genocide. Importantly, in Iraq the atrocities perpetrated against the Kurdish people are uncontroversially described as genocide. These developments represent milestones in the acceleration of wider debate and action for the significant recognition and internationalization of Kurdish Genocide.

In 1980 Iraq openly abolished the Algiers Agreement, driving the nation into war with Iran (better known as the Persian Gulf War or the Gulf War), one of the longest wars in the history of the Middle East (1980-88). Motivated by both his fear that the 1979 Iranian Revolution would inspire the Shia' majority in Iraq to rebel and his thought that the revolution had weakened the Iranian political and military forces, Saddam Hussein waged an invasion via air and land on Iran in 1980 following the long dispute over border and waterways. However, Iran proved a tough enemy as it soon repelled the Iraqi forces and regained its control over all lost territories by 1982 . (Gunter, 2003, 131) ${ }^{5}$ In the final stages of the war, the Iraqi economy was deteriorating, and Saddam Hussein felt further threatened by the truce between the joint Kurdish forces of KDP and PUK and the Iranian government. Responding to this alliance, he appointed his cousin Ali Hasan Al-Majid to command the Northern Bureau of the Ba'ath. (Yildiz, 2004, 25)

Al-Majid, who was given absolute power, headed a series of systematic genocidal attacks against the Kurdish population in the north known as the Anfal Campaigns or the Kurdish Genocide. Extending from 1986 until 1989 and culminating in 1988, the Anfal Campaigns were mainly meant to settle the Kurdish question in Iraq definitively. ${ }^{6}$ In the first months of his administration, Al-Majid started a wave of raceclearance in the Kurdish villages, destroying hundreds of them and relocating their inhabitants into governmental camps. He also used chemical weapons against the town of Halabja (the Halabja Massacre) on 16 March 1988, killing more than 5000 people and causing the death of many others of complications, diseases, and birth defects. Yildiz asserts that what distinguished Anfal from the previous military attacks was the systematic use of chemical and deadly gases against the civilian population. Although exact figures have never been established, the Anfal campaigns resulted in "the physical destruction of an estimated 3000 villages, the displacement of approximately 1.5 million people and the mass execution of civilians...it is believed that up to 180.000 people were killed." (Ibid) The final waves of 
the campaigns saw the heaviest increase in the elimination of Kurdish civilians because of false promises of a general amnesty. The final Anfal campaign was commenced on 25 August 1988 with poison and gas attacks on the villages of Bahdinan to crush the Kurdish resistance controlled by the KDP. (Ibid)

Despite the international responses to the Anfal campaigns, the Iraqi forces continued on their systematic racial clearance of the Kurds up until Iraq's invasion of Kuwait and the outbreak of the Iraq War 2003 and the invasion of Iraq by a United States-led coalition that overthrew the government of Saddam Hussein; a conflict that continued for over a decade due to the emergence of an insurgency to oppose both the occupying forces as well as the post-invasion Iraqi government. Consequently, the invasion, which occurred as part of the war against international terrorism, caused a gravely unsettled political and economic atmosphere that dominated the country and led to a state of complete security deterioration. Today, the violence that started years ago with the genocidal Anfal continues to hover over the persisting political conflicts and the epidemic phenomenon of corruption prevalent in Iraqi and Kurdish society, which are obviously factors contributing to the perpetration and enhancement of violence and terrorism.

A significant explanation for the prevalence of criminal and terrorist groups in conflict-torn Iraqi society is the absence of solid security systems and political integration that prevent their emergence or suppress their growth. The omnipresence of corruption within the public sphere advances the criminal and terrorist operations through facilitating the creation of organized crime groups, which are likely to forge alliances with both domestic and international terrorist groups. A comprehensive and multidisciplinary attention has been paid to the genocide of the Yezidi Kurds in Sinjar. According to Paulo Pinheiro, the Chair of independent international Commission of Inquiry "Genocide has occurred and is ongoing; ISIS has subjected every Yazidi woman, child or man that it has captured to the most horrific of atrocities." 7 The Commission of Inquiry determined that ISIS's barbarity against the Yazidis amounts to crimes against humanity and war crimes.
The cultural and social structure of Iraq including the contradictions between the rural and urban areas, the national divisions, and Iraq's long regional wars are some of the conditions discussed in most of the scholarship on the emergence of ISIS in Iraq. An important element in the theorization of the ISIS ideology is the personal grievances of some individuals and communities to react against repressive regimes they aspire to change. While local grievances can be directly associated with domestic terrorism, the coming of ISIS has made all the difference in the heated atmosphere of the political and religious disputes in Iraq and led to the emergence of international terrorism, represented by ISIS.

In a surprisingly short time, ISIS was able to seize control over Mosul and the surrounding towns and districts. As part of their program to exert chaos, lawlessness and sectarian hatred, ISIS soon freed thousands of prisoners, destroyed important religious monuments and shrines and archaeological sites and threatened civilians. Upon its first entrance into Mosul, ISIS issued the 'City Document,' a constitution that demanded the immediate departure of Christians and Shabak Shiites from Mosul or they would face conversion or death. In the Iraqi Women Journalists Forum held in 2015, Suha Auda explains that:

The organization executed large numbers of women and men. It carried out a massive campaign, arresting dozens of women who were taken to Daesh 'Sharia Court'... Eight or nine mass graves have so far been found inside and outside Mosul... Currently, Daesh carries out its executions in the streets and public markets; they are filmed and openly disseminated on social media. (Auda, 2015: 2)

The ISIS broadcasting of these atrocities is depicted as part of the psychological war that the group is fighting alongside the physical war they have waged on land. Footage of tortures, beheadings, mutilations, and combustion of terrified people is disseminated around the world and particularly amongst the Kurdish population of Iraq, who were most directly affected. The Kurdish writer Arsalan Rahman emphasizes the importance of military media, war correspondents, and expertise in the strategies of psychological war against ISIS:

ISIS has successfully implemented the tactics of psychological war as well as new 
technological sciences in communicating its messages and propaganda. They have also successfully occupied the thinking and mind-set of the population and effectively used it for their advantage. (Arsalan, 2015: 124)

Though ISIS has been perpetrating numerous atrocities in the cities and towns they have entered, Sinjar witnessed the perpetuation of the most notorious operations. The report of the Holocaust Museum, based on the research of Naomi Kikoler, the deputy director of the museum, asserts that thousands Yazidis have been killed, detained, or run away to Mount Sinjar where they were besieged for weeks by militants. Though the report maintains that ISIS have executed crimes against humanity and war crimes against Christians, Turkmen, Shabaks, and other minorities, only the Yazidis faced systematic acts of genocide. In addition to killing thousands of Yazidis, Kikoler explains in the report that during her trip to northern Iraq in 2015 she witnessed genocidal acts at first hand:

We heard harrowing accounts of displacement, forced conversion, rape, torture, kidnapping and murder. We saw first-hand traumatic consequences of those atrocities and of mass displacement...We saw angst born from the uprooting of religious practices, the erosion of identity, and the tearing apart of communities. (Kikoler, 2015: 2)

Unlike most tragic events in Kurdish history, the bloody rampage of Sinjar met with great resonance in the media as well as worldwide political forums. The notorious acts of destroying complete villages such as Kocho village $^{8}$, the killing and enslaving of thousands of men and women, and the raping and sexual abuse of hundreds of girls and women were shocking to the whole world, who witnessed the events on news broadcasts, TV screens, and social media networks. Reporting these atrocities only a week after they occurred, Vian Dakheel, the only Yazidi female MP, addressed the Iraqi Parliament and urged them to immediate action. Despite the parliamentary Speaker's repeated requests to confine her remarks to the matter of her original statement, Dakheel insisted on making a highly emotional plea:

Mr. Speaker, until now 500 Yazidi men have been slaughtered. Mr. Speaker, our women are being taken as slaves and being sold in the slave market. Please, brothers... There is now a campaign of genocide being waged on the Yazidi constitute... Brothers! Away from all political disputes, we need humanitarian solidarity. ${ }^{9}$

Dakheel's plea, "Brothers! I speak in the name of humanity. Save us. Save us!" headed news and press bulletins around the world. Her speech provoked the Iraqi Parliament to send humanitarian airdrops for the thousands of escapees besieged on Mount Sinjar and to support those who had run away to safer areas. Dakheel's speech, which was filled with pain and horror and quickly spread via social media, not only drew worldwide attention to the Yazidi plight, but also generated an international humanitarian effort and military support: "President Obama claimed her emotional plea influenced his decision to allow US forces to take part in the air operations." 10

Due to the enormous brutalities that the Kurdish genocide exerted, politics of genocide recognition have long been engaged both by Kurdish and non-Kurdish groups inside and outside Kurdistan, including members of the KRG, members of the KRG bureau of representation in Europe, and of the Iraqi Kurdish diaspora in Europe. Both Anfal and the Sinjar genocide have long acquired an important position on the KRG's political agenda as well as mobilized diaspora organizations across Europe. The importance of genocide recognition stems from the fact that:

It fosters a victim-based approach to human rights and justice. It helps restore dignity to victims, and contributes to healing wounds through rehabilitation, memory, recognition and prevention. It reinforces the rights of Iraqi Kurds as victims to be honoured and remembered. This, in turn, promotes trust between different communities. It allows them to confront the past and possibilities for the future; it acknowledges massive abuses, the annihilation of Iraqi Kurds, and the tragic loss of life. ${ }^{11}$

Moreover, as confirmed by Bahar Baser and Mari Toivanen, "the KRG's official documents formulate demands for genocide recognition within the framework of human rights, restorative justice, and genocide prevention instead of referring to an eventual secession." (Baser and Toivanen, 2017: 14) Hence, genocide recognition should be understood within the 
frame of the ongoing humanitarian as well as nation-building processes.

\section{Violence in the Kurdish 'Conflict Zone' as represented in Hizar and the Vicissitudes of Life, Part One}

Throughout the last three decades, the Kurdish genocide of 1988 has become a significant theme in a variety of contexts including the evolving Kurdish novelistic discourse. Kurdish authors have tried to represent the horrible tragedy in various formats: short stories, novels and documentaries of different forms.

Kurdish novel in Bahdinan have been, since its first emergence in the late 1980s, representing various forms of war-related and terrorismrelated violence and depicting the notable increase in the number of civilian casualties as well as the physical and psychological impacts of war and genocide on the lives and experiences of Kurdish people in Iraq. The description provided by Wenona Giles and Jennifer Hyndman's about the ending of boundaries between combatant spaces and civilian spaces is adopted in this study to investigate the atrocities of the Ba'ath regime, including the genocidal Anfal Campaigns and the terrorist attacks and invasion of ISIS in 2014 against the Kurdish population in the north of Iraq. Giles and Hyndman indicate that, unlike wars fought in the past, when civilian peoples' homes were safe and male soldiers fought enemies on battlefronts, "contemporary conflicts blur such distinctions, rendering civilian women, men, and children its main casualties." (Giles and Hyndman, 2004: 4) In their assertion of the way homes have been transformed into battlefronts, they further add that:

While "home" was once demarcated as a "private" space beyond the purview of public responsibilities, violence perpetrated at home is increasingly understood as part of broader social, political, and economic processes that are embedded in state policies, public institutions, and the global economy. (Ibid)

Important manifestations of the blurred boundaries between military and civilian sites are depicted in Kurdish novels by Bahdini authors including both parts of Sindis Niheli's Hizar Di Werçerxana Da, Bergê Êkê, (Hizar and the Vicissitudes of Life) Part One, 2013 and its second part, published in 2014, with the same title, which chronicle the atrocities perpetrated against Kurdish people during the Anfal campaigns between 1986 and 1989 .

Niheli's text expresses various historical aspects of Kurdish women's lives with a particular focus on the personal experiences of the writer as expressive not only of the lives of her female protagonist but also of the collective Kurdish experience in Iraq. Writing from a feminist perspective, Niheli focuses on the life and experiences of a female character and depicts her transformation from a hopeless victim to a well-informed social and political activist. She writes with a sense of responsibility to her nation by narrating the story of a regular woman that will otherwise remain marginalized and invisible. The story of Hizar, the female protagonist, reveals the hard trajectories and painful reality affecting Kurdish people in Iraq.

Niheli, born in 1987 in Duhok, aims to depict the historical experiences of conflicts and wars of the Kurds in Iraq and their struggle to assert their national and cultural identity. Niheli is the very first woman writer in Bahdinan to produce a novel written in the Kurdish language and has received much recognition and awards from the local literary and feminist institutions and agencies for her book. She has published a number of poems and short stories in the local magazines and newspapers. In an interview with Evro daily newspaper, Niheli compares Hizar, the female protagonist in both parts, to Layla Qasim and Layla Zana in terms of her persistent and tireless struggle for the creation of a liberated and independent Kurdish state. ${ }^{12}$ Niheli interweaves themes of historical and national struggle with questions of gender roles and women's participation in the Kurdish national struggle.

Told through not only Hizar's voice, but also that of her lover, Ako the Peshmerga, her friend, Shavin as well as an unknown narrator, the novel traces Hizar's experiences that encompass the horrible events of the Anfal campaigns, the 1991 Gulf War, the Kurdish popular Uprising, the creation of a de facto Kurdish state in the north of Iraq, the Kurdish civil war between the dominant political parties, and their later reunification. The narrative opens at an unspecified point during the Anfal campaigns with images of people leaving their homes to escape the growing Iraqi air raids. While Niheli makes visual use of imagery to open the novel, she tends mainly to employ imagery in a way that invites reading it symbolically. Most of these images evoke sensory experiences associated with fear, destruction, and death; familiar aspects of war. For example, in one of the opening passages, we are told that:

Streets and valleys were soon filled with people. Tanks and mountain guns began to fire. The smock from burning villages, mountains, and crops turned our day into a dark night. The smell of burning human flesh soon mingled with the smells of blood and gunpowder. (Niheli, $2013-10)^{13}$ 
With this opening scene, Niheli introduces Rizgar, one of Hizar's relatives, who has just recently lost his wife, trying to save the lives of his mother, four sisters and little child. The situation is worsened by the intensity of bombing and his child's death from hunger. We soon realize that these images are haunting Hizar's mind as the scene shifts to Hizar, currently a political activist studying in the US and working at a Kurdish radio station called Khin (Blood). She is on her way with Ako, going to a governmental institution to invite some diplomats and officials to the public discussion of her doctoral thesis. This eloquent juxtaposition of past and present events is one of the defining features of the text and the book clearly follows this structural line through its focus on Hizar as a victim of war and political conflicts (past) and a political activist (present). Niheli's identification with the turmoil of her nation becomes evident throughout the novel and Hizar, who devotes her entire life to the national cause of her people, is a clear embodiment of such identification. She is exposed to various levels of oppression before and after her involvement in the national movement. In a seminar she presents in Washington at the request of some diplomats to define Kurdish nationalism, she confirms that her personal story is the story of Kurdish oppression as well as Kurdish resistance. Describing the Anfal campaigns, Hizar says:

I was only fourteen when the Iraqi forces attacked us. They gathered us all in a field...killed men with rocks that smashed their heads...rivers of blood started running... Women and girls started screaming...The forces separated women from men and pulled them into military trucks... As I watched through the window, I saw my fiancé Nazi, handcuffed, being beaten to death by two security policemen. $(60-61)^{14}$

As indicated in this passage, the war in Kurdistan defies the conventional spaces of the "gendered dichotomized" roles of war with men at the front and women safely at home. Unlike most narratives that depict war as a central theme, Niheli does not need to connect the war fronts with the home as the war zone is the characters' very homes and villages. Accordingly, Kurdish women as well as men were victims to cruel State-sponsored operations of genocide and ethnic cleansing. As the narrative goes on, more and more images of the horrible atrocities of the Ba'athist regime during the Anfal campaign are illustrated. Women, who were pulled into military trucks, were taken to concentration camps miles away from their original towns and villages. Having some nursing experience, Hizar volunteers to help the survivors of the chemical weapons. The images are terrifying:

Oh. Most of them were blind. Some have lost parts of their bodies. Cries of pains from burns of mustard gas and cyanide reached the sky... A pregnant woman died in front of my eyes and I saw her baby's movement stopping inside her belly...I was ordered to inject two little very sick boys but they couldn't make it. Then I realized the injections were poisonous... when I refused to give more, an officer started beating me with his belt. $(65-67)^{15}$

The narrative delivers concrete instances of the ways women were exposed to verbal and physical abuse. In one instance, Hizar describes how the Iraqi forces "would walk around the piles of women and choose some. Then, they would undress them and sexually violate them in front of the rest of us and they would even film their monstrous atrocities." $(68)^{16}$ Describing her experiences during an investigation by an Iraqi officer years later, Hizar cries as she remembers the way she was beaten and threatened with rape if she did not give information about her fellow activists. When some guests ask her how it was that she could survive the experience, she is traumatized and leaves the hall. Ako continues the seminar and starts with an apology:

Please forgive her. Her burden is very heavy and much beyond her powers. She fights on behalf of forty million Kurds. She struggles to gather the fragmented pieces of her nation. She wants to dry the tears from her mother's eyes and stop the bloodshed from her heart. She hopes to bring a smile back into her mother's lips. (80) ${ }^{17}$

Because of the very brutal methods employed by the Ba'ath secret police and security officers during investigations, the memories of her days in prison keep haunting Hizar. The far-reaching implications of imprisonment for the Kurdish people are evident in the fact that these institutions were the first targets of the Kurdish rebellions during their national Uprising:

There was no more fear. Everyone participated. We entered the Iraqi security building...the walls were all covered with blood and human flesh hung from the ceilings. But these were familiar images to me since I had been into such places. I had seen people being beaten, whipped, tortured, and executed. (106) ${ }^{18}$

Hizar, however, is not the only character in the novel who suffers from painful memories of wars, imprisonment and torture. For example, despite his attempts to repress the horrific experiences of war, Tangazar, Hizar's friend, still undergoes long periods of psychological distortions in which he refuses to see or talk to anyone. He tells Hizar: 
Days and nights of continuous wars, many people were killed, many were injured and many were imprisoned... Women who were only seventeen to twenty-five-year-old were irresponsibly abused and raped. The open fields were replete with women's blood. Acid was thrown all over their bodies. On that morning, I ran away thinking of the mass killing of my mother, my wife and sisters. (197) ${ }^{19}$

Accordingly, descriptions of the Kurdish conflict zone, like many contemporary zones of ethnic-nationalist conflict in Africa, the Middle East, and Asia, resist the traditional outlines of conflict zones. Armed conflicts in the militarized Kurdish areas can be defined in relation to Giles and Hyndman's formulation of a conflict zone whereby they assert that:

Notions of what constitutes a conflict zone are similarly outdated. The idea that (feminized) civilian and (masculinized) military spaces are distinct and separate no longer holds. Civilian homes may be technically out of bounds according to rules of war, specifically the Geneva Conventions, but in practice, they are often targets. Noncombatants are supposed to be safeguarded from war, with fighting duties assigned toward soldiers, yet civilians compose the vast majority of causalities in current conflicts. (Giles and Hyndman, 2004, 5)

Depicting war and armed conflicts through the perspective of women, the novel portrays gender roles in times of war and displacement. By 1987, Kurdish women, who have historically been involved in the Kurdish national movement, became the direct targets of the Ba'ath military operations. The Anfal campaigns and the following events represented dangerous turning points for them, as their roles were no longer restricted to the struggle to survive war and sanctions or mourn the prisoners or the dead. The complex blurring of borders between home and front in conflicted zones is well described by Giles and Hyndman who argue that throughout much of the world, where war and battlefronts used to be quite separated from people's homes, now war is increasingly waged on civilian women, men, and children:

In every militarized society, war zone, refugee camp, violence against women and men is part of a broader continuum of violence that transcends the simple diplomatic dichotomy of war and peace...While "home" was once demarcated as a "private" space beyond the purview of public responsibility, violence perpetrated at home is increasingly understood as part of broader social, political, and economic processes that are embodied in state policies, public institutions, and the global economy. (Giles and Hyndman, 2004: 3-4)
In the "militarized society" of Iraqi Kurdistan, Kurdish people were treated as dissidents that needed to be eliminated. Given the history of Kurdish national struggle against the Iraqi governments, the homes of civilian Kurds were usually transformed into battlefronts where they were exposed to direct armed conflicts. According to Giles and Hyndman, the analysis of combatants (men) / civilian (women) sites in conflict situations addresses "the politics of social and economic disparities and explore possibilities for changing power imbalances that include gender relations." (Giles and Hyndman, 2004: 4) Hence, through linking sites of war and peace, Hizar and the Vicissitudes of Life, Part One maintains that strategies for conflict resolution and peace-building cannot be implemented until an understanding of the gendered politics that perpetuate and administrate violence is provided.

\section{Kurdish People Encountering a New War in Hizar and the Vicissitudes of Life, Part Two}

Niheli's Hizar and the Vicissitudes of Life, Part Two, 2014 opens with a prediction of conflict. Early in the text, a character remarks that, "in the nearest future, many incidents will happen and the Kurds will fall into deep and serious troubles and miseries." ${ }^{20}$ It is this period of foretaste of future prospects experienced by the Kurdish people of Iraq, and the hectic period immediately following that form the primary focus of this section. This phase of the recent Kurdish history in Iraq is characterized by a significant lack of security, unconcealed interethnic and sectarian hatred and conflict, most prominently between the Shiite and Sunni Arabs, and extensive political struggles both between the central government in Baghdad and KRG and within KRG itself. All these conditions serve as a fertile ground for the formation and growth of criminal and terrorist ideology.

The current war imposed on Kurdish people and the rest of Iraq is an indication of the blurring of boundaries between the home and war front, particularly in the aftermath of September 11, 2001 terrorist attacks by the alQaeda terrorist group. This aspect of the war in IKR receives further attention in this section given the growing numbers of civilian causalities and the increased confrontation of the private/public, national/international, combatant/civilian spaces and how such conflicts are directly influencing Kurdish literary production. The turn to civilian casualties and terrorist battlefronts is confirmed, yet again, by Giles and Hyndman:

Noncombatants are supposed to be safeguarded from war, with fighting duties 
assigned to armed soldiers, yet civilians compose the vast majority of casualties in current conflicts. Whereas most casualties at the turn of the nineteenth century occurred among soldiers at the battlefront, civilian deaths and injuries constituted 60 to 80 percent of casualties at the end of the twentieth century. (Giles and Hyndman, 2004: 5)

This argument is even more applicable, taking into consideration the war on terror, also known as the Global War on terrorism waged by the USA against al-Qaeda and other related terrorist organizations after the September 11 terrorist attacks. The war on terror in Afghanistan, in Iraq, and the various operations conducted in other countries, is characterized more than anything by the ever-growing number of civilian casualties reaching as high as over 90 per cent of the deaths. The text asserts that boundaries of war fronts and militarized zones are steadily affected by cultural, economic, political, and religious ideologies, which shape identities and civilizations. It is indicated in this section that because wars occur within the boundaries of states with high levels of civilian casualties, gender has become a highly significant aspect in the current conflicts. Giles and Hyndman's introduction confirms this:

The incorporation of civilians into contemporary conflicts has been a highly gendered practice. It has occurred on the finest spatial scale: that of the human body, a site always marked by relations of gender, class, nation, race, caste, religion, and geographical location. (Giles and Hyndman, 2004: 5)

In addition to the depiction of the various forms of control and domination exerted within and by a patriarchal Kurdish society, the texts selected here present the violated female body as a site where ideological conflicts take place, as women are captured, raped, tortured, and murdered. Set in the same geographical context as part one, part two portrays the same characters involved in a new war that is directly targeting their homes. Though considerably shorter than part one, the second part continues and resumes Hizar's experiences depicted in the first book and completes both the narrative left open by the end of part one and the circle of the vicissitudes through which Hizar goes. In an interview with Waar (Country) daily newspaper published in Duhok, Niheli explains these vicissitudes:

The novels picture Hizar moving through four historical stages: Anfal and Halabje, the Uprising and the mass-exodus, the civil war and the liberation of Iraq in 2003, and the endless political and administrative corruption. (Gaberki, 2015: 11)
This chronological order of events in both parts demonstrates most obviously Niheli's methodical concern to bear witness to the tragic history of the Kurdish people and their constant struggle for independence. While the narrative follows the life and personal experiences of Hizar, it confirms that Hizar is a representative of her people. The first part closes with Hizar identifying herself as a Kurd while engaged in a defense for the right of the Kurds to establish an independent state: "I am a Kurd. A Kurd. An independent Kurdistan is my right... Why should my country be called Iraqi Kurdistan? Why is an independent Kurdish state still considered a red line?" (272-273) Part Two of the novel opens with a similar concern of Hizar with her nation:

Oh, Kurdistan. We are dreamers and we know our hopes. The shadows of yesterday will not last longer. We live in today and tomorrow is smiling on us... The ruins of years of struggles, martyrs, Anfal, loss, injustice and oppression should stimulate the national feelings in all politicians. (9) ${ }^{21}$

Niheli's conclusions regarding the future of Kurdish politics are expressed through the characterization of Ako. All through both parts of the novel, his behavior and attitudes reflect the political conditions of Kurdistan. He is described as a visionary nationalist who vigorously struggles for Kurdish rights and identity and advocates Kurdish political independence. He is endowed with stereotypical characteristics of a Peshmerga: physical strength, braveness, military prowess and perpetual loyalty to the Kurdish cause. As part of the Kurdish population in Iraq, Ako has experienced oppression, escape, hunger and homelessness and has lost many members of his family during the Anfal campaigns. As a Peshmerga, he has participated in wars and insurgencies against the $\mathrm{Ba}$ 'ath regime and has continuously suffered the horrific impacts of these wars. Ako undergoes a state of temporary alteration in which he transforms from a loving and caring husband to a cruel abusive man. Though in the second part, which opens almost six years after the action of the first part, Ako has been killed six months ago during the Kurdish war against ISIS, similar moments of love and passion continue to appear through Hizar's recollections of their days together. Her memories, however, are occasionally disrupted by instances of Ako's tangled emotions and psychological disintegration following the political upheaval immediately preceding the ISIS invasion of Iraq.

Involving a detailed documentary analysis of the recent powerful emergence of ISIS, Niheli's novel describes, almost halfway through the text, 
the advances of the militant organization benefiting from the on-going civil war in Syria and transferring recruits and resources to Iraq from their positions in the bordering cities and towns there. The narrator also describes the easy submission and capitulation by the Iraqi military, which obviously facilitated the advances of the jihadists. The text elaborates on the manipulative attitudes of ISIS towards the Kurds, first announcing they would not approach the Kurdish regions, and later making a sudden incursion into Kurdistan. Despite their initial claim, ISIS soon attacked the Kurdish territories, overrunning the unprepared Kurdish forces in such towns as Sinjar, Makhmour, and Gwer, only fifteen miles from Erbil, the capital city. The fear generated by this swift incursion is palpable in Niheli's text:

The black soldiers approached the Kurdish land and confidently announced they would pray for Eid in Sinjar, the land of struggle and resistance. People in the very city I live in started preparing for an escape when the threats became very close. (44) ${ }^{22}$

The memories of the misery and violence she has experienced during the Anfal Campaign are brought to life again because of the ISIS attacks as Hizar encounters familiar images of the destruction of a nation she has worked all her life to defend. As these images and memories are brought back to life in Hizar's mind, it becomes as if she is living the same violence represented in the images she sees on TV of the Kurdish people on Mount Sinjar:

The smell of dead bodies and the fading cries of those who have survived are making the high mountain a silent cemetery. The poverty, nakedness and hunger, the messiness of the hair and the dryness of the faces of those besieged on the mountain with no water or food are heartbreaking images. The human tragedy, the innocent victims and the new wave of immigrants that is splitting parents and their children is repeated. The winds of death that crush the hopes and wishes of children and youths are blowing again. (47) 23

Hizar's contemplation of the tragic events of Sinjar invigorates her memories of the experiences of Anfal, Halabje, the Uprising and the following upheaval in which she witnessed the destruction of her village and the death of her father and many other family members. In addition to being extremely notorious and brutal, the ISIS attacks on Sinjar and the other parts of Iraq are characterized by the exertion of outrageous acts of gender violence. While Hizar and the Vicissitudes of Life, Part Two, does not chronicle the specific experiences of the Yazidi women in captivity, it does address the sexual violence imposed on them:
ISIS victimizes the Yazidis. The black soldiers are eating the red flesh of infants and drinking young men's blood like wine. They are breaking the bones of old people and beheading tough men. They are raping girls and abusing women. (47) 24

Vivid imagery is deployed to delineate ISIS practices of sexual violence and gendered abductions as part of their strategies to spread fear and chaos in Sinjar and the rest of Kurdistan. Although Hizar is not physically affected by the atrocities of ISIS in Sinjar, as she had been involved in the previous incidents such as the Anfal and the 1991 exodus, her contemplations serve to bring to the fore the horrific reality of the experiences of Kurdish women in the grip of ISIS.

\section{CONCLUSION}

Throughout the last three decades, Kurdish Genocide has been increasingly employed as a significant area of focus in a variety of contexts and a substantial body of scholarly and academic effort has gone into the investigation and elaboration of the subject. Through criticals investigation and close textual and contextual readings of Niheli's Hizar and Vicissitudes of Life, Parts One and Two, the present study has asserted that Kurdish novelistic in Bahdinan is highly concerned with the representation of Kurdish Genocide as an active platform to support the recognition of Kurdish Genocide and human rights in Kurdistan. Representation of Kurdish Genocide, whether the 1980s Anfal Campaigns or the Sinjar genocidal attacks in 2004 also contributes to such significant processes of restoring the dignity of Kurdish people in Iraq through acknowledgement, memory and rehabilitation.

Through the portrayal of the inner feelings that Hizar experienced during the genocide of Anfal and its aftermath, alongside her sufferings as a result of the loss of her husband in the Kurdish fight against ISIS, the text epitomize the attempts of Kurdish authors in Bahdinan to chronicle events that changed history in Kurdistan and write testimonies that represent the hidden voices of the victims. The voices of the survivors, on the other hand, can provide different perspectives on the genocide and its aftermath as manifested through the stories told by Hizar and the other characters. 


\section{FOOTNOTES}

${ }^{1}$ Wenona Giles and Jennifer Hyndman, eds. Sites of Violence: Gender and Conflict Zones (Berkeley, Los Angeles, London: University of California Press: 2004), 3 .

2 https://en.wikipedia.org/wiki/Genocide_Convention

3 The Kurdish Genocide Achieving Justice through EU Recognition.

${ }^{4}$ Ibid.

5 According to Michael M. Gunter, Ali Hasan AlMajid is the "cousin of Saddam Hussein who was given unprecedented powers to act ruthlessly against the Kurds when he was appointed secretary general, or governor, of the Baathist Northern Bureau in northern Iraq on 3 March 1987.”

6 The 1988 Anfal Campaign in Iraqi Kurdistan, Online Encyclopedia: http://www.massviolence.org/the-1988-anfalcampaign-in-iraqi-kurdistan

7 UN Commission of Inquiry on Syria: ISIS is committing genocide against the Yazidis. https://www.ohchr.org/FR/HRBodies/HRC/Pages/Ne wsDetail.aspx?NewsID=20113\&LangID=F

8 A small village in Sinjar, Kocho witnessed the most brutal acts of genocide by ISIS. According to many news sites, only 200 of its 1700 Yazidi inhabitants survived.

9 YouTube, "Iraqi Yazidi MP Breaks Down in Parliament: ISIL is Exterminating my People," (August 2014), https://www.youtube.com/watch?v=HdIEm1s6yhY 10 Abigail Haworth, "Vian Dakhil: Iraq's only female Yazidi MP on the battle to save her people," The Guardian (February, 2015), 3.

11 The Kurdish Genocide Achieving Justice through EU Recognition.

12 Layla Zana is the wife of Mehdi Zana (1991present), mayor of Diyarbakır and the first Kurdish woman in the Turkish parliament. She is very wellknown for her support and contributions to the Kurdish movement in Turkey.

13 All further references to this work will be cited in the text by page number in parentheses. All English in-text quotations from this work are my own translation and will be annotated throughout the thesis with the original corresponding passages from the Kurdish (Bahdini) text.

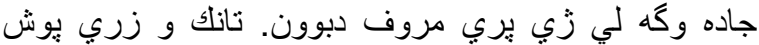

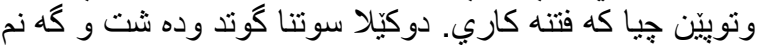

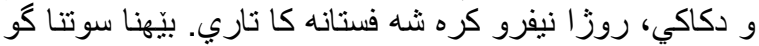

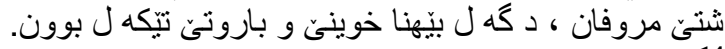

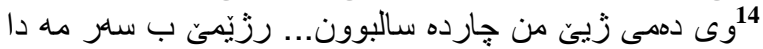

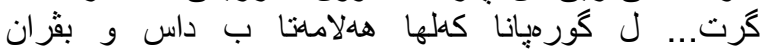

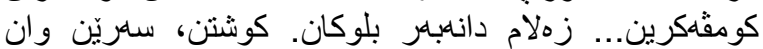

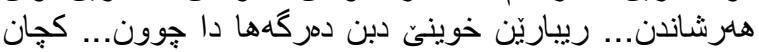

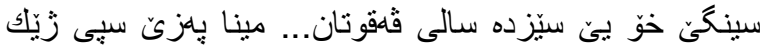

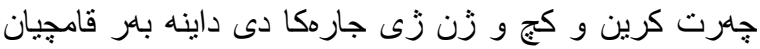

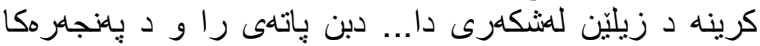

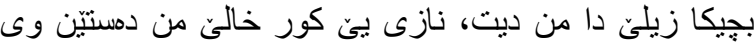

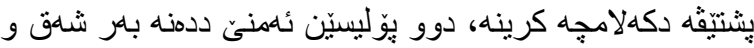

رَّيَّان.

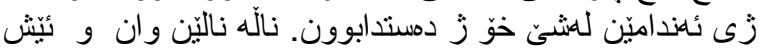

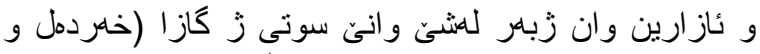

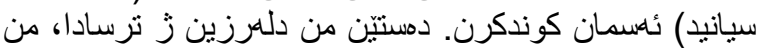

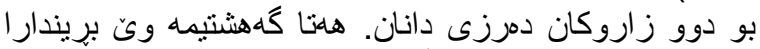

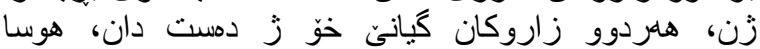

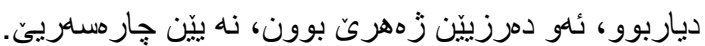

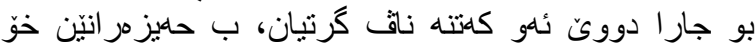

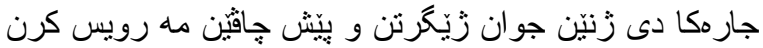

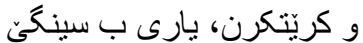

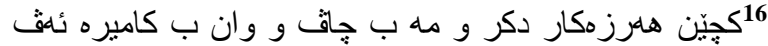
ديمهنه ويّنه دكرن.

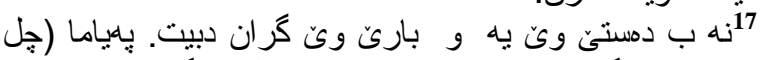

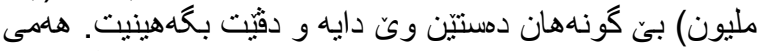

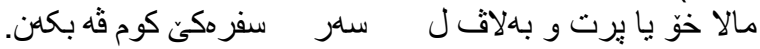

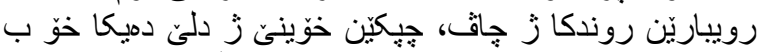

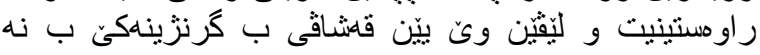
خثينيت.

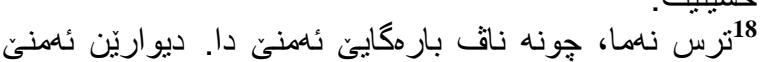

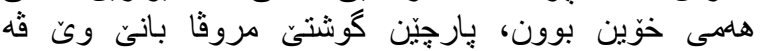

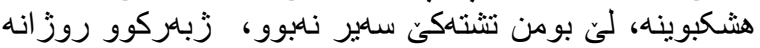

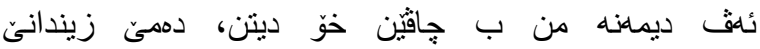

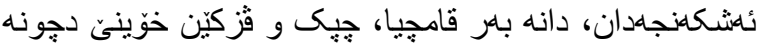

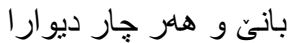

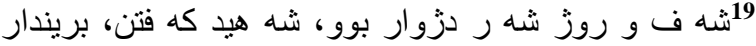

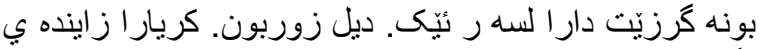

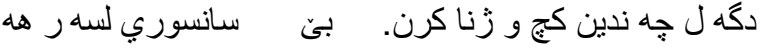

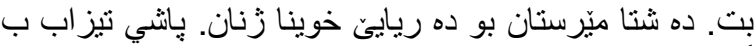

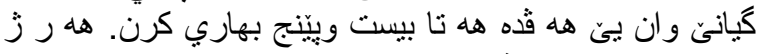

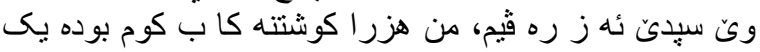

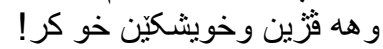

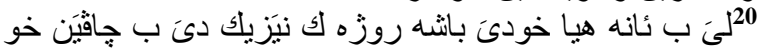

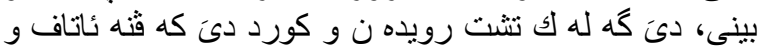

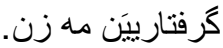

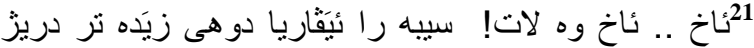

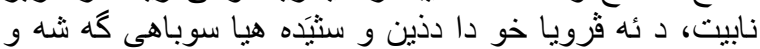

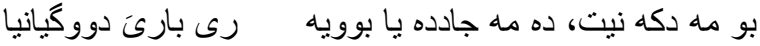

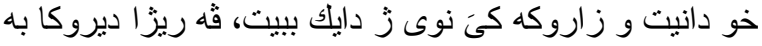

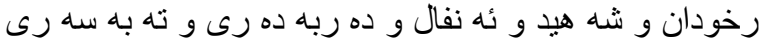

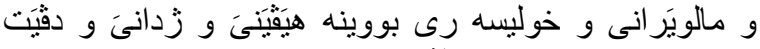

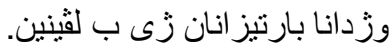

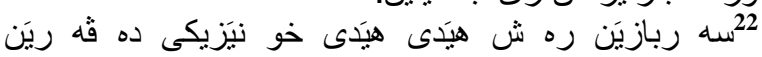

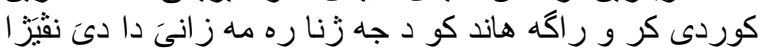

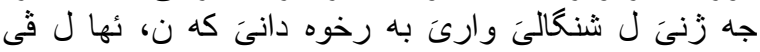

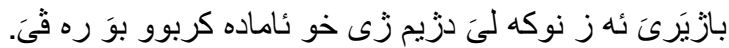




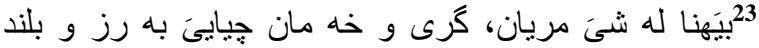

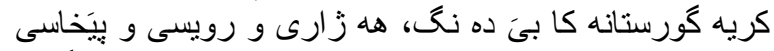

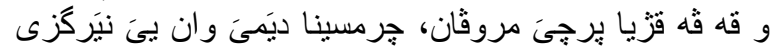

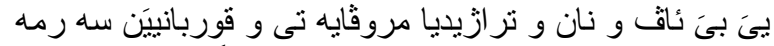

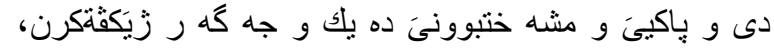

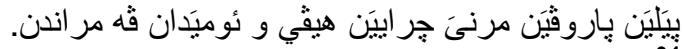

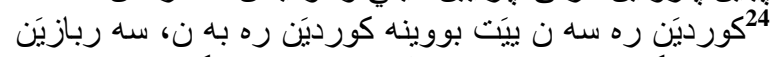

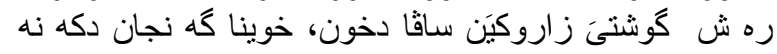

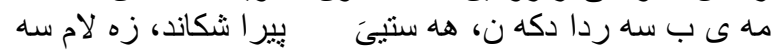

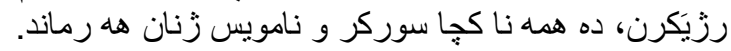

\section{REFERENCES}

- Arsalan R. (2015). Sherê Deroni Da'esh u Rengdanewey le Midyay Kurdi da (The Psychological War: Daesh and its Reflection in the Kurdish Media). Hawler: Rozhhalat Press.

- Baser B. and Mari T. (2017). "The Politics of Genocide Recognition: Kurdish Nationbuilding and Commemoration in the PostSaddam Era." Journal of Genocide Research, 19:3, 404-426.

- Gaberki B. (2015). Hozanvana Genc bu Waar: Mn Hizar wek Jinek b Hêz d Diroka Kurdi da Wêne krye (The Young Novelist to Waar: I Have Portrayed Hizar as the Brave Women in the Kurdish History) Waar Daily Newspaper, 1257.
- Giles W. and Hyndman J. (2004). Eds. Sites of Violence: Gender and Conflict Zones. Berkeley, Los Angeles, London: University of California Press.

- Gunter, M. M. (2003). The A to Z of the Kurds. Maryland: The Scarecrow Press.

- Haworth A. (2015). "Vian Dakhil: Iraq's only female Yazidi MP on the battle to save her people," The Guardian.

- Mustafa R. (2015). Cinematizing Genocide: Exploring Cinematic Form and Its Relationship to The Hidden Voices of The Kurdish Genocide of 1988, Unpublished PhD, University of Salford, Salford, UK.

- Naomi K. (2015). "Our Generation is Gone: The Islamic State's Targeting of Iraqi Minorities in Ninewa," Imon-Skjodt Center for the Prevention of Genocide and the United States Holocaust Memorial Museum.

- Niheli S. (2013). Hizar and the Vicissitudes of Life, Part One. Duhok: Khani Press.

- Niheli S. (2014). Hizar and the Vicissitudes of Life, Part Two. Duhok: The Press of Duhok Governorate.

- Suha A. (2015). "The Mosul Crisis: its Roots, Daesh's Terrorist Practices, and their Impact on Women." ICSSI Editor, 2.

- Yildiz, K. (2004). The Kurds in Iraq: The Past, Present, and Future. London: Pluto Press. 